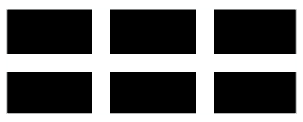

ThE WILLIAM DAVIDSON INSTITUTE AT THE UNIVERSITY OF MICHIGAN BUSINESS SCHOOL

\title{
Embracing the Market: \\ Entry into Self-Employment in Transitional China, 1978 -1996
}

\author{
By: Xiaogang $W u$
}

William Davidson Working Paper Number 512

September 2002 


\title{
Embracing the Market: Entry into Self-Employment in Transitional China, $1978-1996^{\dagger}$
}

\author{
Xiaogang $\mathrm{Wu}$ \\ Population Studies Center \\ University of Michigan, Ann Arbor
}

(Approximate word count 11,300)

\footnotetext{
${ }^{\dagger}$ Direct all correspondence to Xiaogang Wu (email: xgwu@umich.edu), Population Studies Center, University of Michigan, 426 Thompson St., PO Box 1248, Ann Arbor, MI 48106-1248. The data collection was supported by grants from the National Science Foundation (SBR9423453), the Luce Foundation, the Ford Foundation, and the University of California Pacific Rim Program. I thank Donald Treiman for making the data available to me, and Deborah Davis and $\mathrm{Yu}$ Xie for helpful comments. The research was supported by a postdoctoral fellowship from the Andrew W. Mellon Foundation.
} 


\title{
EMBRACING THE MARKET: ENTRY INTO SELF-EMPLOYMENT IN TRANSITIONAL CHINA, 1978-1996
}

\begin{abstract}
This paper introduces labor market transition as a mediating process by which the macro institutional transition to a market economy alters social stratification outcome. Rather than directly addressing income distribution, it examines the pattern of workers' entry into selfemployment in reform-era China (1978-1996). Analyses of data from a national representative survey in China show that education, party membership, and cadre status all deter urban workers' entry into self-employment, whereas education promotes rural workers' entry into selfemployment. As marketization proceeds, the rate of entry into self-employment increases in both rural and urban China, but urban workers are increasingly more likely to take advantages of the new market opportunities, and urban college graduates and cadres are becoming more likely to do so in the later phase of reform.
\end{abstract}

Key words: Labor Market, Rural China, Self-employment, Transition, and Urban China JEL Classification Codes: J4, J40, J23 
William Davidson Institute Working Paper 512

\section{EMBRACING THE MARKET: ENTRY INTO SELF-EMPLOYMENT IN TRANSITIONAL CHINA, 1978-1996}

\section{INTRODUCTION}

During the past decade the literature on social stratification in post-socialist societies has mushroomed (e.g., Bian and Logan 1996; Gerber and Hout 1998; Griffin 1993; Lin 1995; Nee 1989a, 1991, 1996; Parish and Michelson 1996; Rona-Tas 1994; Stark 1996; Szelenyi and Kostello 1996; Xie and Hannum 1996; Zhou 2000a). Theoretical debates are centered on market transition theory. Advocates of the theory (Cao and Nee 2000; Nee 1989a, 1991, 1996; Nee and Cao 1999; Nee and Matthews 1996) claim that, as marketization proceeds, returns to human capital (particularly to education) will increase, whereas the influence of political capital (particularly to communist party membership and cadre status) will decline. Other scholars contend that the redistributive power can still exert a substantial impact on the post-socialist stratification, due either to the persistence of the old system (e.g., Bian and Logan 1996) or to the conversion of power into new market advantages (Hankiss 1990; Rona-Tas 1994; Staniszkis 1991). Empirical findings on income/earnings distribution in post-socialist societies so far have been inconclusive, and the adjudication of controversies has been hampered by several conceptual and measurement problems (see comments in Cao and Nee 2000; Zhou 2000b).

First, institutional transition from a redistributive economy to a market economy is a complex process in which many facets are affected simultaneously. Changes may occur at the levels of enterprises (Guthrie 1997; Nee 1992), local governments (Walder 1995), labor markets (Zhou, Tuma and Moen 1997), communities (Lin 1995), or social relationships (Wank 1996). Without defining a concrete institutional context within which marketization takes place, it is hard to gauge its impact on the structure of social inequality (Wu 2002; Zhou 2000a). This partly 
explains why scholars cannot agree upon a single and generic measure of marketization (Hauser and Xie 2001; Nee 1996; Walder 1996; Xie and Hannum 1996).

Second, the transition per se is a dynamic process. The decades-long economic reforms in both China and Eastern Europe have experienced various phases, in which the relative strength of the market vis-à-vis the redistributive state has altered significantly. In the early phase, the newly emerging market was marginal to the entire redistributive economy, whereas in the late phase it has become a significant agent in allocating resources and generating inequality. The question of whether certain social actors have benefited from the increasing marketization is too vague to answer, unless the concrete institutional parameters of marketization are specified (Szelenyi and Kostello 1996). Winners under certain circumstances could become losers when circumstances have changed (Wu and Xie 2002).

Third, in most research designs, using income/earnings as the main proxy of social stratification outcome in the post-socialist era has received much criticism (Oberschall 1996; Zhou, Tuma and Moen 1997). Because under state socialism a portion of economic rewards usually took the form of redistributive benefits such as housing and welfare provided by work organizations (Bian 1994, Chapters 7-8), cash income may be an inadequate measure of social inequality. In the reform era, although communist cadres may have reaped profits from the market, any incomes reported from those sources were difficult to gauge (and likely undermeasured) with questionnaire surveys. Moreover, since income became a more important social stratification indicator in the reform era than in the pre-reform era, income inequality may have resulted from the varying pace of change in reward forms from non-monetary welfare to cash income, rather than from marketization per se. 
This is not to say that income distribution should be discarded in the studies of socialist and post-socialist social stratification. The problem lies in the disjunction between the overarching concept of institutional transition and its distributional consequences. Whereas income is chosen as a specific outcome of stratification, the labor market - the corresponding concrete institution that directly produces income inequality - is largely neglected in the literature mentioned above (except for Gerber 2003). As the market sector expands and offers more lucrative rewards, workers' transition to the market sector is an important path of socioeconomic mobility. Because workers' labor market transition is a process mediating between macro institutional change and individual's earned incomes, researchers must first examine the process of workers' labor market transition and its structural constraints, an integral part of the multi-facet market transition process, before addressing social outcomes caused by such a process.

In this paper I direct attention to the labor market as a central institution in examining social consequences of market transition in China. Rather than focusing on income/earnings as a specific distributional outcome, I examine the patterns of Chinese workers' entry into selfemployment, an important way of improving income and living standards. Rather than treating China as a homogenous country, I demonstrate how the patterns of transition vary between rural and urban China, where labor market structures are shaped by different pre-existing institutions and reform strategies. Rather than simply asking who won and who lost, I portray a dynamic picture of social actors in market transition. 


\section{MARKET TRANSITIONS AND LABOR MARKET TRANSITIONS}

For most of its history, state socialism prohibited private ownership of the means of production. The Stalinist model of planned economy was built on the monopoly of all resources, including labor, by the hand of the state (Kornai 1992). Without free labor markets, labor assignments were governed by bureaucratic principles rather than the market rules. In urban China, the government labor/personnel bureaus allocated workers to work units, where they stayed and received wages, housing, and social services (Bian 1994; Walder 1986). In rural China, through the household registration system (hukou), most peasants were confined in their home villages (Wu and Treiman 2002) and received "work points" and food rationing from the rural collective (Parish and Whyte 1978).

Economic reforms introduced the market mechanism into socialist economic operations with the intent of increasing productivity and raising living standards. Starting in the late 1960s, Hungary allowed peasants and workers to be involved in private household farming or other corporate entrepreneurial activities (Rona-Tas 1994; Stark 1989; Szelenyi 1987, 1989). In 1978 the household responsibility system was instituted in rural China, which allowed peasant households to arrange agricultural production schedules and to retain the residual grain after fulfilling the government's procurement quota. Freed from the land, many peasants began to participate in non-agricultural private businesses (Qian 1999; Nee 1989b). Meanwhile, to tackle the urban unemployment issues in the early 1980s, the Chinese government also endeavored to promote individual family businesses (getihu) or private enterprises (siying qiye) to provide jobs for the returning "sent-down" youth and new school graduates (Gold 1991). Moreover, the opening-door policy attracted a huge amount of foreign direct investment and created new types of ownership in the Chinese economy, including joint-ventures, share-holding, foreign-funded, 
and overseas Chinese-funded companies (Qian 1999). These firms, coupled with domestic individual businesses and private enterprises, constituted an expanding market sector outside redistribution. The coexistence of redistributive and market sectors characterizes socialist mixed economies in Eastern Europe prior to 1989, and in urban China to date.

The paths of transition in Eastern Europe and China diverged in the 1990s. Whereas Eastern Europe (as well as the Soviet Union) adopted a strategy of transforming its redistributive economies through radical privatization after the regimes collapsed, China continued an incremental approach to expanding the non-state sectors, which acted as the primary thrust of economic transition (Pei 1996). In 1984, the state industry was still central to China's national economy, but by the end of 1998, without closing down or privatizing state-owned enterprises, the state economy was no longer the major component of the economy (Qian 1999). As clearly shown in Figure 1, from 1980 to 1998, the share of China's gross industrial output by the private sector increased from almost none to about one-third, while the share by the state sector declined from 70 percent to 20 percent. ${ }^{1}$

The divergent patterns of economic transitions have heavily shaped the opportunity structure in labor markets. The radical privatization programs implemented in Eastern Europe and the Soviet Union after1989 resulted in capitalist or capitalist-oriented economies, in which the old communist elite suddenly lost the power and privileges associated with the redistributive system (Szelenyi and Kostello 1996). Entrepreneurial activities were likely the best opportunity for them to seek new advantages. Several studies found that a group of communist elite

${ }^{1}$. The interpretation of the portion of collective economy is ambiguous. Most industrial outputs by collective enterprises are due to rural township and village enterprises (TVEs), which, on the one hand, are controlled by local governments and communities and, on the other hand, are operated according to market principles beyond state redistributive plans (Peng 2001). Some are essentially private enterprises with "red hats" designed to protect themselves from the environmental uncertainties (Nee 1992; Qian 1999). 
Figure 1. Gross Industrial Output by Ownership: 1980-1998, China Data Source: China Labor Statistics Book 1999

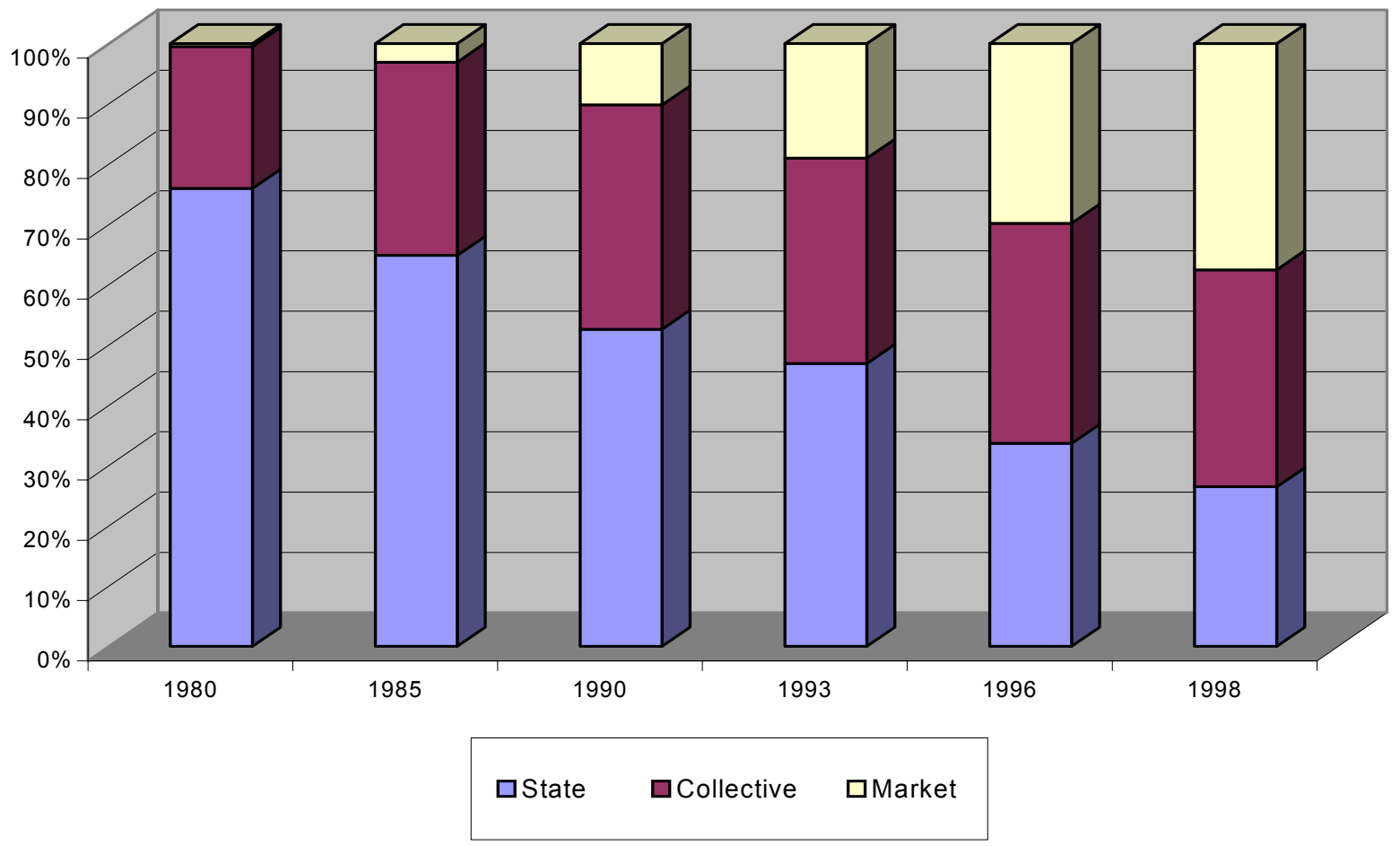

members (technocrats) have made successful transitions to corporate/private entrepreneurs and self-employees, who seemed to have done better than workers of other backgrounds (Gerber 2000; Hankiss 1990; Hanley 2000; Rona-Tas 1994; Staniszkis 1991).

In urban China, however, the socialist mixed economy renders a dual opportunity structure in labor markets, though the advantage has recently shifted more toward the market. While the state remains the predominant employer in providing social security, fringe benefits, and political advancement, the market sector offers more entrepreneurial opportunities. Especially in a new round of market reform after 1992, more and more professionals and government officials became engaged in market activities ("jumped into the sea" or xiahai) (Chen 1993; Wu and Xie 2002).

In rural China such a duality of labor markets is nonexistent. Under the household registration system (hukou), peasants (workers with rural hukou) were entitled to few of the rights and benefits that the state conferred to urban workers (Wu and Treiman 2002). Peasants' 
lack of vested interests in the old system made it possible to sweepingly dismantle the rural commune system soon after 1978 (Oi 1990), ${ }^{2}$ and to develop a relatively homogeneous rural labor market. In terms of wage determination, the rural public sector (e.g., TVEs) is similar to the rural private sector, but sharply different from the urban public sector (Peng 1992; Walder 1995).

Due to the different labor market structures, urban and rural China could have very different patterns of labor mobility. In urban areas, the state sector is still able to attract quality workers, although the market sector offers increasingly lucrative alternatives. In rural China, the state sector offers essentially no career paths to peasants, which means that making money in the market is the only way that rural household/residents (including cadres) can reduce their socioeconomic disadvantages (relative to urban residents). Many rural families have been involved in non-agricultural businesses in the reform era (Entwisle et. al. 1995).

Institutional theorists employ the concept of path dependence to account for both the continuity in institutional change and the variability of institutional environments (North 1990). In the analyses of post-socialist social stratification, the first issue has been well taken, typically in explaining the persistent advantages held by communist party members or cadres (e.g., Bian and Logan 1996; Nee and Cao 1999; Stark 1992; 1996). However, little attention has been paid to the diversity of institutional environments within a society. To shed light on the multifaceted scenarios of post-socialist transition and different social outcomes in China, a comparative study of patterns of labor market transition between rural and urban areas is thus in order.

\footnotetext{
${ }^{2}$ In 1977 several households in a village in Fengyang County of Anhui province initiated a reforming practice, in which they signed contracted with the local government to deliver a fixed quota of grain in exchanging for farming on a household basis. In the following year the Chinese Communist Party endorsed the so-called "the household responsibility system," which was expanded nationwide by 1984 (Qian 1999).
} 


\section{PATHS TO THE MARKET IN RURAL AND URBAN CHINA}

Workers' entry into self-employment is path-dependent on at least two interrelated factors: the relative strength of the market vis-à-vis the state, and workers' vested interests in maintaining their status quo. As the market sector expands in the whole economy and the political risk of market activity decreases, the likelihood of self-employment increases. Also, as the expected gains from the market sector exceed vested interests in the old system, the likelihood increases.

Market transitions in rural and urban China follow distinctive paths. Soon after the rural reform started, the commune system in rural China was completely abolished, whereas the redistributive sector in urban China continues to this day. The role of redistribution is much weaker in the rural economy than in the urban economy. Moreover, under the different opportunity structures in labor markets, peasants have few vested interests in maintaining their current status as compared to urban workers, who must weigh the loss of welfare benefits provided by their work units against the potential of entrepreneurial activities when deciding on entry into the market (Davis 1999). Therefore, it can be inferred that, other things being equal:

- Hypothesis 1: Rural workers have a higher rate of entry into self-employment than urban workers.

The role of human capital and political capital has been a central issue in the studies of social consequences of post-socialist transition. Human capital investment in education has been linked to entry into self-employment/entrepreneurship in both post-1989 Hungary (Rona-Tas 1994) and post-Soviet Russia (Gerber 2001, 2003), as it has in some Western capitalist societies (e.g., Evans and Leighton 1989; Carr 1996). However, contrary to the claims made by market transition theorists, the effects of redistributive attributes have not declined. Former cadres are more likely than others to become corporate entrepreneurs in Hungary (Rona-Tas 1994); and 
communist party members are also at an advantage for entry into self-employment in post-Soviet Russia (Gerber 2003).

This path of transition is contingent upon the circumstance under which the redistributive sector no longer offers attractive careers. In rural China, much like post-1989 Eastern Europe and Russia, a lack of opportunity in the state sector has resulted in an influx to the market, generally among those with human capital. As Nee (1989b) noticed, the early rural Chinese entrepreneurs tended to be sent-down urban educated youth who stayed, urbanities who returned to their villages, demobilized soldiers, production team cadres, and artisans, who in general possessed some marketable skills. However in urban China, although the new market sector has started offering attractive salaries, the state remains the main provider of material rewards and life chances to well-educated workers and political loyalists (Walder 1995; Walder, Li and Treiman 2000). Surveys conducted in the mid-1980s have shown that most urban private entrepreneurs and self-employees (getihu) came from lower tiers in the redistributive hierarchy - that is, migrant peasants, unemployed youth, returning sent-down youth, dismissed employees, and retirees (Li 1993: 323-30).

Hence, rural and urban self-employment entrants may differ substantially in their social backgrounds. Education, which denotes human capital, is expected to assume a different role in determining market entry in rural and urban China.

- Hypothesis 2: Education deters workers' entry into self-employment in urban China while it increases workers' entry into self-employment in rural China.

Controversies have arisen mainly with regard to the role of political capital, usually measured by communist party membership and/or cadre status, in the course of market transition. Studies of post-1989 Eastern Europe and Russia have found evidence supporting the “power-conversion” thesis (Gerber 2001; Hankiss 1990; Rona-Tas 1994; Staniszkis 1991): 
former cadres or communist party members were more likely to be involved in entrepreneurial activities once they saw the collapse of state socialist regimes inevitable. On the contrary, because the communist party is still firmly holding power in China and offers career opportunities and welfare benefits, workers with political capital are less likely to give up their jobs in the urban state sector. However, such retaining effects are nonexistent in rural China, political capital, measured by party membership and cadre status, is thus expected to play a different role in determining market entry.

- Hypothesis 3a: Party membership deters entry into self-employment in urban China, but not in rural China

- Hypothesis 3b: Cadre status deters entry into self-employment in urban China, but not in rural China.

\section{DYNAMICS OF ENTRY INTO THE MARKET}

Market transition is a dynamic process. Workers' entry to the expanding market sector is dependent upon the relative strength of the market vis-à-vis the state and workers' vested interests, which not only differ between rural and urban areas, but also vary across different phases of marketization. In the early phase of reform (Hungary and Poland from the mid-1960s until around 1980, and in China between 1978 and the mid-1980s), the private economy was introduced into the socialist planned economy merely as a secondary and complementary element. ${ }^{3}$ Because the market activities then were politically risky, the major body of people involved in market activities tended to be from the marginal groups in the socialist hierarchy, who had little to lose. Success in the market required little skills and education.

\footnotetext{
${ }^{3}$ Szelenyi and Kostello (1996) term this institutional arrangement between markets and redistribution as "local markets in redistributively integrated economies." In the Chinese Communist Party's documents, the tenet is called "planning as a principal part and market as a supplementary part" (jihua wei zhu shichang wei fu) (Qian 1999).
} 
As the market gained more legitimacy, and played a greater role in economic operations, the political risks of involving in market activities decreased considerably. In Eastern Europe between 1980 and 1989, and in China after 1986, workers with relatively more marketable skills and education started entering the marketplace, and even more workers earned extra cash income through second jobs in the market. Cadres and their children also began to build bridges to the market and cash their bureaucratic privileges as well (Nee and Lian 1994; Stark and Nee 1989; Szelenyi 1988, 1989; Szelenyi and Kostello 1996; Walder 1995).

After the collapse of the communist regimes in Eastern Europe in 1989, the implementation of rapid privatization programs resulted in "capitalist-oriented economies," in which the market arose as a dominant mechanism (Szelenyi and Kostello 1996). In China, a more market-oriented economy had been gradually developing since 1992 , when the Party's $14^{\text {th }}$ Congress endorsed the blueprint of building up "the (socialist) market economy" (shehui zhuyi shichang jingji). A variety of lucrative opportunities became available in emerging real estate markets and financial markets. Meanwhile, with the coverage of the social security net extended, the risks in the market sector were further reduced. Under these circumstances, professionals and cadres became increasingly engaged in market activities. ${ }^{4}$

The dynamics of labor market transition imply that advantages shift according to the concrete institutional circumstances associated with different phases of marketization. In the early phase, ordinary workers and peasants may have benefited from participating in the market. However, in the later phase, when people with more human capital and marketable skills, or the

\footnotetext{
${ }^{4}$ According to the PRC Ministry of Personnel, in a single year of 1992 more than 120,000 cadres resigned from their government posts and joined in the market (xiahai) (Chen 1993). Li and Hong (1995) estimated that from 1992 to 1993, about 300,000 administrative officials/staff switched to the market sector.
} 
technocratic fraction of cadre members, entered the market, the early pioneers were pushed to the marginal positions and lost their advantage (Szelenyi and Kostello 1996; Wu and Xie 2002).

Hence, this dynamic process fosters the following empirically testable hypotheses:

- Hypothesis 4: As the reform proceeds, the likelihood of entry into self-employment will increase. This may be particularly true in urban areas where marketization was accelerated later.

- Hypothesis 5: As the reform proceeds, the likelihood of entry into self-employment will increase for higher educated people.

- Hypothesis 6a: As the reform proceeds, the likelihood of entry into self-employment will increase for party members.

- Hypothesis 6b: As reform proceeds, the likelihood of entry into self-employment will increase for former cadres.

Hypothesis 4 suggests that market expansion would offer more entrepreneurial

opportunities; Hypotheses 5, 6a, and 6b posit that an expanded, less risky market sector would attract more workers with educational or political credentials away from careers in the state sector. The changing composition of market entrants not only has significant bearing on stratification outcomes, but also suggests the increasing desirability of careers in the market sector for capable workers, which itself reflects the institutional transition from state socialism to market capitalism.

\section{DATA AND THE DEPENDENT VARIABLE}

The empirical analyses presented here are based on the survey of "Life Histories and Social Change in Contemporary China" (1996), a multi-stage stratified national probability sample of 6,090 adults aged 20-69 from all regions of China (except Tibet). The survey gathered extensive information on respondents' life histories and job activities. Because life in rural and urban China is very different, samples from rural and urban areas were drawn separately, yielding 3,003 rural cases and 3,087 urban cases (Treiman 1998: Appendix D). These two samples are combined, with appropriate weight, to form a national probability sample of Chinese population. 
This paper investigates the process of entry into self-employment during the period 1978 to 1996 , in both rural and urban China. I select 1978 as the benchmark year because it is the year when China's economic reform started. I choose entry into self-employment as the dependent variable because it not only reflects individual preferences (as in western capitalist economies), but more importantly the structural change in the relative strength of the market vis-à-vis the state in a transition economy (Zhou, Tuma, and Moen 1997). In the market transition era, engagement in self-employment (individual business and private entrepreneur) is generally viewed as offering new opportunities for workers that can significantly improve income and living standards (Gerber 2001; Rona-Tas 1994).

Conventionally, self-employed workers are "individual business owners" (getihu) or "private entrepreneurs" (siying qiye zhu) ${ }^{5}$ However, in China workers can be engaged in entrepreneurial activities without necessarily changing their occupations (Davis 1999). In addition, corporate entrepreneurs who do not receive regular salaries are not included in the two categories above. Hence, here I use a broader criterion to define self-employment: if one's main source of income is from running business as "head of enterprises or individual entrepreneurs," or "self-employed professionals,"(ziyou zhiye) or "helping out family enterprise or business," then $\mathrm{s} /$ he is coded as a self-employed worker.

Figure 2 plots the percentages of self-employed workers, based on both narrow and broad definitions (i.e., "occupation" and "main source of income"), in the urban and rural labor forces from 1978 to 1996 . Throughout the reform era, the percentages of self-employed workers increased. The rural-urban gap, which was almost nonexistent prior to 1985 , widened

${ }^{5}$ According to China' regulations, private-owned businesses with fewer than 8 employees are registered as getihu, whereas the businesses with 8 or more employees are registered as "private enterprises"(siying qiye) (Wang 2001). 
significantly beginning in 1986; by 1996 self-employment among urban workers was more than twice as high as among rural workers.

The following analyses are based on the broader definition of self-employment. I first test the hypotheses regarding the rural-urban differences in patterns of self-employment, using crosssectional data from 1996. Then I examine how the role of human capital and political capital changes in different phases of transition in both rural and urban China, using the event history data from 1978 to $1996 .{ }^{6}$ Finally, I discuss the implications of my findings, particularly in terms of social outcomes of the post-socialist transition.

Because the Fugure 2: The Percentages of Self-Employment in the Rural and research design necessitated clusternng the sample within 100 city Trobsen I show Enwen (TTwe Dafinitinme)

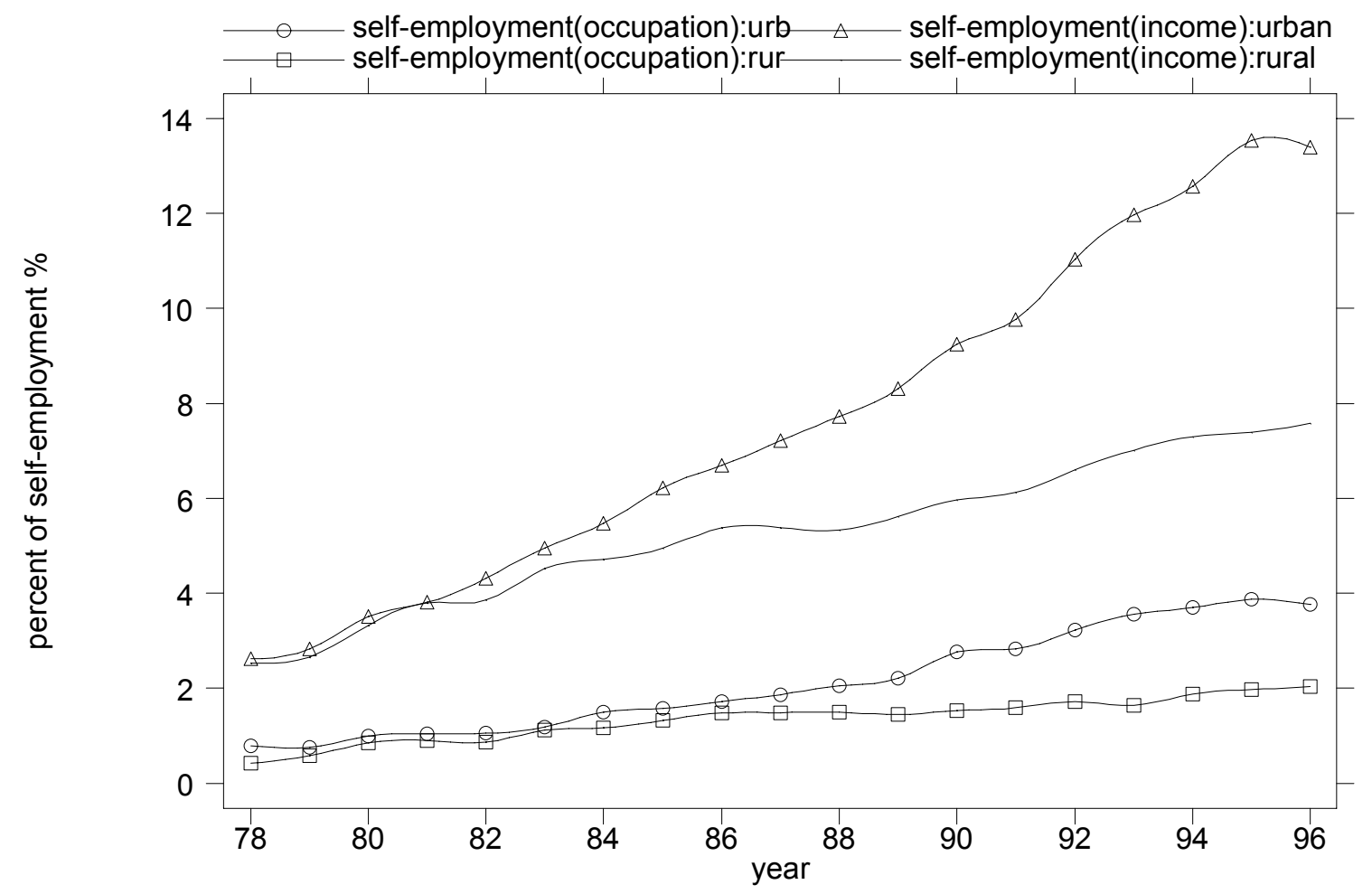

districts/counties (see details in Treiman 1998), an adjustment on standard errors is needed in

${ }^{6}$ The cross-sectional analyses of entry into self-employment defined based on occupation yield similar results, which are available upon request. Event history analyses cannot be carried out due to the small number of cases. 
both logit models and hazard models. All the models reported were estimated using Stata 7.0, with robust standard errors to correct the clustering on sampling units (districts/counties) (Stata Corp. 2001). The data were also weighted to represent the Chinese general population.

\section{RURAL-URBAN DIFFERENCE IN PATTERNS OF ENTRY INTO SELF- EMPLOYMENT}

\section{Models and Variables}

I first fit a binary logit model to predict whether a respondent is self-employed as of 1996 . The model is specified as:

$$
\log \left(\frac{p_{i}}{1-p_{i}}\right)=\beta_{i 0}+\sum_{k=1}^{K} \beta_{k} x_{i k}
$$

where $p_{\mathrm{i}}$ is the probability that $i$ th individual is self-employed in $1996, \mathrm{x}_{\mathrm{ik}}$ is the $k t h$ independent variable for $i$ th individual, and $\beta_{\mathrm{ik}}$ is the respective coefficient.

To examine the rural-urban difference in patterns of self-employment, I estimate the equation for the urban and rural samples separately, and apply t-tests to compare the magnitude of the coefficients.

The main independent variables of interest in the logit model are human capital, denote by education, and political capital, denoted by communist party membership. Education is measured in years of schooling completed. Because the effect of education may not be linear (e.g., see Luber et al. [2000] for West European countries; Robert and Bukodi [2000] for Hungary), a square term of education is added to the models. Party membership is coded as a dummy variable (yes $=1$ ). Other independent variables are included as control variables. Age is measured as the difference between 1996 and the respondent's birth year, and gender is coded as a dummy variable (male $=1$ ). Parent's party membership is a dummy variable indicating 
communist party membership for one or both parents (yes $=1$ ). Parents' self-employment status when the respondent was age 14 is coded in the same way as the dependent variable.

Because large regional variations in economic structure and the pace of marketization create varying labor market opportunities (Xie and Hannum 1996), the region of residence may also affect entry into self-employment. All provinces/provincial-level jurisdictions are mapped into four relatively homogeneous regions and denoted by a set of dummy variables in the models. Guangdong is a southern province in which marketization is far ahead of that in the rest of China (Vogel 1989). Beijing, Shanghai, and Tianjin, or "directly-administered municipalities," are metropolitan cities with a great expanding market sector. "Coastal provinces" include Fujian, Jiangsu, Shandong, and Zhejiang, where the marketization started early. "Inland provinces" include the rest of provinces, where the economic reform has lagged behind.

Table 1 presents the summary of the variables discussed above. The first three columns describe the characteristics of the national sample, the urban sample, and the rural sample, respectively. The last two columns summarize the characteristics for urban and rural selfemployed workers. As of 1996 about 10.5 percent of all Chinese workers were involved in selfemployment/entrepreneurial activities, but the percentage among urban workers (13.5) is much higher than among rural workers (7.5). Urban self-employed workers have 8.1 years of schooling on average, significantly lower than the average for all urban workers (8.6 years). In contrast, rural self-employed workers have 7.3 years of schooling, significantly higher than the average for all rural workers (5.4 years).

\section{Results}

Table 2 presents estimates of binary logit models on the likelihood of being self-employed as of 1996. Models 1a and $2 \mathrm{a}$ are estimates for the urban sample, and Models $1 \mathrm{~b}$ and $2 \mathrm{~b}$ are estimates 
for the rural sample. Models $1 \mathrm{a}$ and $1 \mathrm{~b}$ include only individual characteristics: education and its square term, party membership, gender, and age. Models $2 \mathrm{a}$ and $2 \mathrm{~b}$ add family backgrounds (parents' self-employment status, parents' party membership) and region.

The intercepts in Models 2a and 2b are both negative, but the intercept in Model 2a is greater than that in Model 2b. A two-sample t-test shows that the difference is statistically significant $(p<.001)$, suggesting that urban workers are relatively more likely to have been selfemployed than rural workers as of 1996, other things being equal (all independent variables take a value of zero, in this case). This finding contradicts Hypothesis 1, which predicted a higher likelihood of self-employment among rural workers than among urban workers. Since rural workers have essentially no state sector alternatives for careers and other life chances, the lower likelihood probably results from structural constraints, i.e., limited market opportunities, in rural areas. Although the market reform started in rural areas, the ensuing expansion of the market economy seems to have favored urban rather than rural workers. ${ }^{7}$

The effect of education on urban self-employment is concave in Model 1a and, even after controlling for age, gender, family backgrounds, and region, in Model 2a as well. That is, the likelihood of self-employment in 1996 first increases with years of schooling, and then

\footnotetext{
${ }^{7}$ One may suspect that our definition of self-employment is subject to an urban bias since "selfemployed professionals" (one of the three categories) are overwhelmingly those residing in urban areas. However, there are only 7 such cases as of 1996, which are unlikely to affect substantive results. In addition, coding self-employment based on main source of income, I have also taken family businesses into account, which are more popular in rural China (Entwisel et. al. 1995).
} 
William Davidson Institute Working Paper 512

Table 1. Unweighted Summary Statistics for Variables in the Logit Models on Self-Employment:

Rural and Urban China, 1996

\begin{tabular}{|c|c|c|c|c|c|}
\hline \multirow[b]{2}{*}{$\begin{array}{l}\text { DEPENDENT } \\
\text { VARIABLES }^{A}\end{array}$} & \multicolumn{3}{|c|}{ Overall } & \multicolumn{2}{|c|}{$\begin{array}{c}\text { Self-employment Market } \\
\text { Entrants }\end{array}$} \\
\hline & National & Urban & Rural & Urban & Rural \\
\hline Percent of Self-employment & 10.5 & 13.5 & 7.5 & - & - \\
\hline \multicolumn{6}{|l|}{ Independent Variables: } \\
\hline Education: & Percent & Percent & Percent & Percent & Percent \\
\hline Junior high school or below & 78.6 & 65.1 & 92.5 & 80.1 & 91.5 \\
\hline Senior high school & 16.1 & 24.8 & 7.1 & 17.0 & 7.6 \\
\hline College or above & 5.3 & 10.1 & 0.4 & 2.9 & 0.9 \\
\hline Party member & 11.6 & 17.4 & 5.8 & 3.1 & 3.1 \\
\hline Male & 50.7 & 49.7 & 51.7 & 57.8 & 72.3 \\
\hline Parent self-employed ${ }^{\mathrm{b}}$ & 5.0 & 7.2 & 2.9 & 12.0 & 8.0 \\
\hline Parental party member & 17.0 & 23.1 & 10.7 & 16.1 & 12.1 \\
\hline \multicolumn{6}{|l|}{ Region: $^{c}$} \\
\hline Inland provinces & 70.7 & 65.5 & 76.0 & 66.7 & 76.3 \\
\hline Coastal provinces & 18.0 & 18.0 & 18.0 & 15.1 & 19.2 \\
\hline Direct municipalities & 5.3 & 10.4 & - & 6.5 & - \\
\hline Guangdong Province & 6.1 & 6.2 & 6.0 & 11.8 & 4.5 \\
\hline Continuous Variables: & $\begin{array}{l}\text { Mean } \\
\text { (S.D.) }\end{array}$ & $\begin{array}{l}\text { Mean } \\
\text { (S.D.) }\end{array}$ & $\begin{array}{l}\text { Mean } \\
\text { (S.D.) }\end{array}$ & $\begin{array}{l}\text { Mean } \\
\text { (S.D.) }\end{array}$ & $\begin{array}{l}\text { Mean } \\
\text { (S.D.) }\end{array}$ \\
\hline \multirow[t]{2}{*}{ Years of schooling completed } & 7.0 & 8.6 & 5.4 & 8.1 & 7.3 \\
\hline & $(4.2)$ & $(4.0)$ & (3.9) & $(3.2)$ & $(3.1)$ \\
\hline \multirow[t]{2}{*}{ Age in 1996} & 41.4 & 42.0 & 40.9 & 38.2 & 35.7 \\
\hline & $(13.0)$ & $(13.5)$ & $(12.5)$ & $(11.3)$ & $(9.9)$ \\
\hline Number of cases & 6086 & 3083 & 3003 & 417 & 224 \\
\hline \\
\hline \multicolumn{6}{|c|}{$\begin{array}{l}\text { Notes: } \\
\text { a. Self-employment (broad definition) is coded based on the respondent's main source of income ("running a } \\
\text { business," or an "independent occupation," or "helping family members' business"); } \\
\text { b. At least one parent in the market self-employment when respondent was at age 14. } \\
\text { c. Inland provinces include Neimenggu, Guangxi, Sichuan, Yunnan, Shaanxi, Gansu, Hebei, Shanxi, Anhui, } \\
\text { Jiangxi, Henan, Hubei, and Hunan, Liaoning, Jilin, and Heilongjiang, Coastal provinces include Jiangsu, Fujian, } \\
\text { Shandong, Zhejiang. Direct Municipalities include Beijing, Shanghai and Tianjin. }\end{array}$} \\
\hline
\end{tabular}


William Davidson Institute Working Paper 512

Table 2 . Coefficient Estimates for Binary Logistic Regression on Self-Employment Entry:

Rural and Urban China, 1996

\begin{tabular}{|c|c|c|c|c|}
\hline & \multicolumn{2}{|c|}{ Urban } & \multicolumn{2}{|c|}{ Rural } \\
\hline Variables & Model 1a & Model 2a & Model 1b & Model 2b \\
\hline Education (in years) & $\begin{array}{l}0.206^{* * *} \\
(0.043)\end{array}$ & $\begin{array}{l}0.193 * * * \\
(0.040)\end{array}$ & $\begin{array}{l}0.277^{* * *} \\
(0.121)\end{array}$ & $\begin{array}{l}0.265^{* * *} \\
(0.125)\end{array}$ \\
\hline Education Square & $\begin{array}{l}-0.023 * * * \\
(0.003)\end{array}$ & $\begin{array}{l}-0.021 * * * \\
(0.003)\end{array}$ & $\begin{array}{l}-0.013 \dagger \\
(0.008)\end{array}$ & $\begin{array}{l}-0.012 \\
(0.008)\end{array}$ \\
\hline Party member (yes $=1)$ & $\begin{array}{l}-1.912^{* * *} \\
(0.325)\end{array}$ & $\begin{array}{l}-1.843^{* * *} \\
(0.326)\end{array}$ & $\begin{array}{l}-0.438 \\
(0.559)\end{array}$ & $\begin{array}{l}-0.427 \\
(0.552)\end{array}$ \\
\hline Male $($ yes $=1)$ & $\begin{array}{l}0.682^{* * *} \\
(0.125)\end{array}$ & $\begin{array}{l}0.649^{* * *} \\
(0.124)\end{array}$ & $\begin{array}{l}0.887^{* * *} \\
(0.178)\end{array}$ & $\begin{array}{l}0.888^{* * *} \\
(0.183)\end{array}$ \\
\hline Age & $\begin{array}{l}-0.029 * * * \\
(0.006)\end{array}$ & $\begin{array}{l}-0.032 * * * \\
(0.007)\end{array}$ & $\begin{array}{l}-0.025^{* *} \\
(0.009)\end{array}$ & $\begin{array}{l}-0.026^{* *} \\
(0.009)\end{array}$ \\
\hline Parent self-employed & - & $\begin{array}{l}0.807^{* * *} \\
(0.249)\end{array}$ & - & $\begin{array}{l}1.375^{* * *} \\
(0.391)\end{array}$ \\
\hline $\begin{array}{l}\text { Parent party member } \\
(\text { yes }=1)\end{array}$ & - & $\begin{array}{l}-0.431^{*} \\
(0.176)\end{array}$ & - & $\begin{array}{l}-0.112 \\
(0.218)\end{array}$ \\
\hline $\begin{array}{l}\text { Region [Inland omitted] } \\
\text { Coastal provinces }\end{array}$ & - & $\begin{array}{l}-0.155 \\
(0.443)\end{array}$ & - & $\begin{array}{l}-0.131 \\
(0.373)\end{array}$ \\
\hline Direct municipalities & - & $\begin{array}{l}-0.288 \\
(0.370)\end{array}$ & - & - \\
\hline Guangdong province & - & $\begin{array}{c}0.327 \\
(0.354)\end{array}$ & - & $\begin{array}{l}-0.176 \\
(0.498)\end{array}$ \\
\hline Constant & $\begin{array}{l}-0.728 \\
(0.362)\end{array}$ & $\begin{array}{l}-0.663 \\
(0.438)\end{array}$ & $\begin{array}{l}-3.160^{* * *} \\
(0.497)\end{array}$ & $\begin{array}{l}-3.114 * * * \\
(0.711)\end{array}$ \\
\hline$\chi^{2}$ & 177.0 & 239.7 & 61.8 & 91.6 \\
\hline Degree of Freedom & 5 & 10 & 4 & 8 \\
\hline Number of Cases & & & & \\
\hline
\end{tabular}

Notes: Figures in parentheses are robust standard errors adjusted for clustering on counties. Data are weighted.

$* * * \mathrm{p}<.001 * * \mathrm{p}<.01 * \mathrm{p}<.05 \dagger \mathrm{p}<.10$ (two-tailed tests). 
diminishes after reaching an optimal number - about 4.5 - of years of schooling (see Figure 3). Because 85 percent of the urban sample completed more than 5 years of schooling (the urban average is 8.6 years), the likelihood of self-employment declines with an increase of education in urban China.

Model $1 \mathrm{~b}$ shows a concave effect of education in rural China as well, with the likelihood of self-employment first increasing and then diminishing with years of schooling, reaching an optimal level at about 11 years (see Figure 3). Since 93 percent of the rural sample has no more than 9 years of education (the rural average is 5.4 years), the effect is largely positive. Indeed, after adding other control variables in Model $2 \mathrm{~b}$, the square term of education becomes insignificant. The relationship between education and the likelihood of self-employment appears positively linear in rural China, which supports Hypothesis 2.

Concerning the effect of party membership, Model 2a shows that party members are less likely to be self-employed than non-party members in urban China. The net odds of selfemployment for a party member are only 16 percent $\left(=\mathrm{e}^{-1.843}\right)$ of the net odds for a non-party member $(p<0.001)$. However, both Models $1 \mathrm{~b}$ and $2 \mathrm{~b}$ show that party membership has no significant effect on the likelihood of self-employment in rural China. These discrepant findings lend support to Hypothesis 3a. Age, viewed as a proxy for years of work experience, is positively related to self-employment in the United States and other developed capitalist societies (Borjas and Bronars 1989; Carr 1996). However, in post-socialist Hungary and Russia, scholars found that age has a negative effect on entry into self-employment (Gerber 2001; Rona-Tas 1994), presumably because older people have invested more in skills specific to the state sector and are thus more averse to change. Similarly in both rural and urban China, age is negatively associated 
Figure 3. The Effect of Education on Probability of Being Self-Employed: Rural and Urban China (1996)

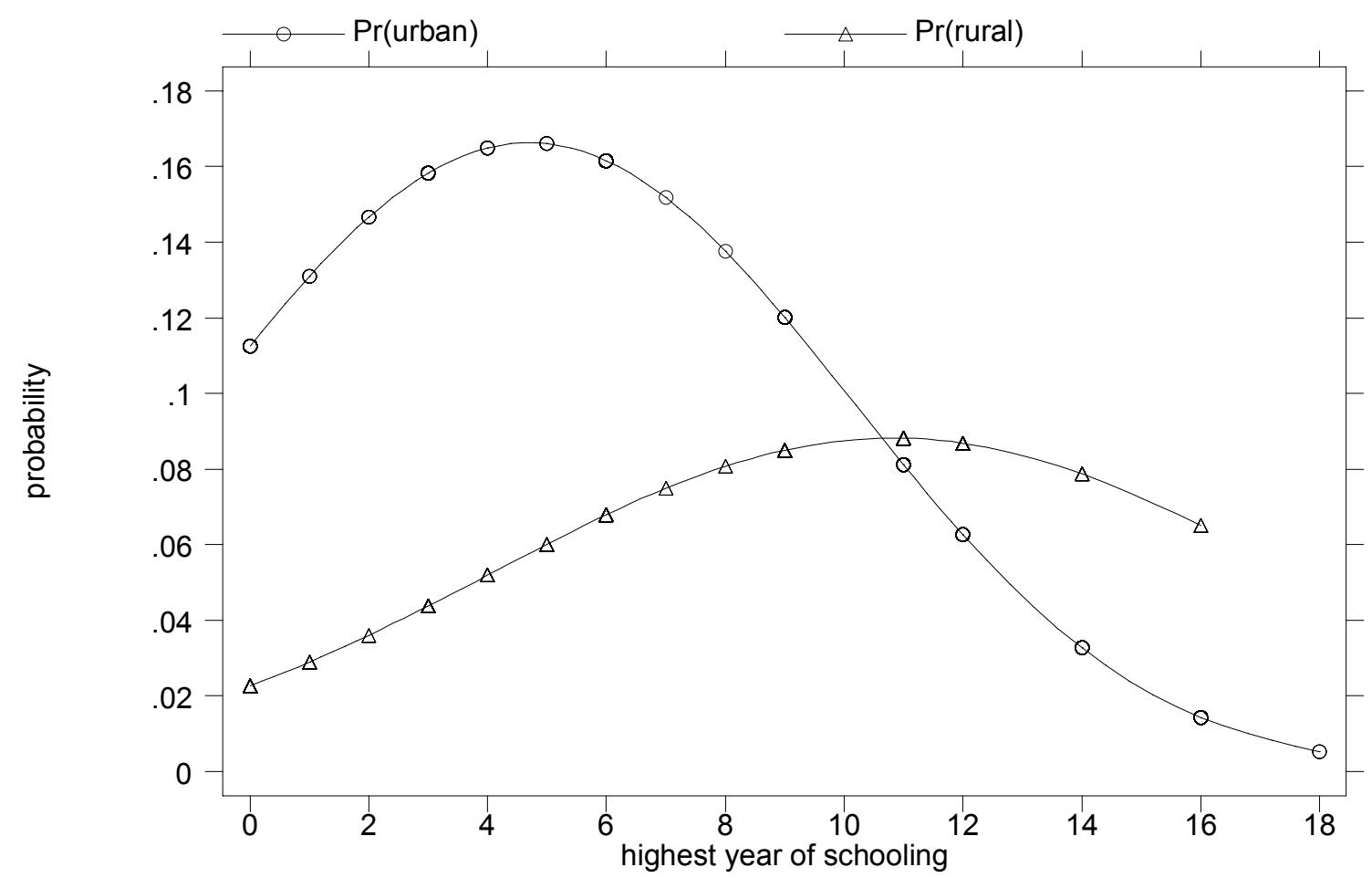

with the likelihood of self-employment. A one-year increase in age reduces the net odds of selfemployment by 3.2 percent $\left(=\mathrm{e}^{-0.032}-1\right)$ in urban China, and by 2.5 percent $\left(=\mathrm{e}^{-0.025}-1\right)$ in rural China.

Traditionally, women have been less likely to become self-employed in both Western capitalist societies and former state socialist societies (e.g. Carr 1996; Gerber 2001; Wharton 1989). China is no exception (Davis 1999; Entwisle et al. 1995). Model 2a shows that the net odds of self-employment are 1.9 times higher $\left(=\mathrm{e}^{0.649}\right)$ for men than women in urban China; Model $2 \mathrm{~b}$ shows the odds as 2.4 times higher $\left(=\mathrm{e}^{0.888}\right)$ for men than women in rural China. Both effects are highly significant $(p<.001)$.

Family backgrounds also have significant effects on the likelihood of self-employment. Having a self-employed parent strongly predicts the respondent's engagement in selfemployment. The net odds of self-employment for people with at least one self-employed parent 
(at age 14) are 2.2 times higher in urban China and 4 times higher in rural China than for people without $(p<0.001)$. Having a party-member parent reduces the likelihood of self-employment in urban China - probably because it increases access to career-path jobs with the state sector - and has no significant effect in rural China.

Since the availability of market opportunities may vary across regions, I include regional variables in Models $2 \mathrm{a}$ and $2 \mathrm{~b}$. Results show that region has no effect on the likelihood of selfemployment in both urban and rural China. For this reason, in addition to the fact that the region's clustering effects have been well accounted for in model estimation, I do not include regional variables in the ensuing event history analysis.

In sum, results in Table 2 present disparate scenarios of workers' self-employment in urban and rural China as of 1996. Consistent with the findings by Zhou, Tuma, and Moen (1997), the state sector in urban China, as the dominant provider of the most lucrative careers, is still able to retain most workers with education and political credentials. Urban self-employment entrants tend to be from the marginal groups in the social hierarchy, i.e., those with less education, no political credentials, and no family connections. However, in rural China, where the state sector offers little competition to the market, education increases the likelihood of selfemployment, while political capital has no significant effect at all.

\section{DYNAMICS OF ENTRY INTO SELF-EMPLOYMENT}

\section{Discrete-Time Hazard Models}

Institutional variations exist not only between rural and urban China, but also across different phases of reform. Because cross-sectional analyses cannot address temporal variations in selfemployment entry patterns, I adopt discrete-time hazard models in event history analysis to examine how the roles of human capital and political capital change over time in relation to self- 
employment. A discrete hazard model involves a shift of the unit of analysis from respondent to life event (i.e., self-employment entry) at a specific time (i.e., year). In this case, all non-selfemployed workers are considered "at risk" of entry into self-employment in each year beginning

$$
p_{i t}=\frac{\exp \left(\alpha_{t}+X_{i t}^{\prime} \beta\right)}{1+\exp \left(\alpha_{t}+X_{i t}^{\prime} \beta\right)}
$$

in 1978. Those who had not yet become self-employed by 1996 are right-censored. ${ }^{8}$

After restructuring the data, a discrete-time hazard model can be fitted (Allison 1982; Powers and Xie 2000). The discrete-time hazard for the $i$ th individual in time period $t$ can be written as a function of $K$ constant or time-dependent covariates, $X_{i t}^{\prime}=\left(x_{i 1 t}, x_{i 2} t, \ldots, x_{i k t}\right)$, The above formula can be expressed in a logit form as follows:

$$
\log \left(\frac{p_{i t}}{1-p_{i t}}\right)=\alpha_{t}+X_{i t}^{\prime} \beta
$$

which can be estimated via a conventional logit model.

Education and party membership remain in the models as the key independent variables. Education refers to the years of schooling completed by the time of entry. Party membership is a dummy variable (yes $=1$ ) that refers to the status prior to a specific year at risk. In addition, I add to the models a dummy variable for prior cadre status (yes $=1$ ), which was not possible to do so in the previously cross-sectional analyses. Prior cadre status refers to the respondent's

\footnotetext{
${ }^{8}$ Although exits from self-employment are likely to occur, the 1996 survey data show that such cases are extremely rare, thus in this paper I only model the first-time entry from 1978 to 1996.
} 
occupation before entry into self-employment. ${ }^{9}$ I combine party membership and cadre status into a three-category variable to measure political capital: $1=$ ordinary worker (neither party member nor cadre); 2 = ordinary party member (i.e., non-cadre); 3 = cadre.

Age, gender, parents' self-employment status, and parents' party membership are also included as control variables. Age refers to the difference between the year at risk and the respondent's birth year and thus, like education and party membership, is a time-dependent covariate. Gender, parent's party membership, and parents' self-employment status are coded as before.

The two-decade-long economic reform in China is divided into three phases. From 1978 to 1986 , the reform was mainly focused on agriculture. Between 1987 and 1991, the reform shifted to cities and a socialist mixed economy emerged. Since 1992, a substantial expansion in marketization ushered in a new wave of entry into self-employment (jump into the sea, or xiahai).

Table 3 summarizes the characteristics of workers who became self-employed during the period from 1978 to 1996 . Over the course of the reform, the annual rate of entry into selfemployment has increased from 5 per thousand to 9.3 per thousand at the national level; this trend is especially prominent in urban China, where the rate has increased from 5.9 per thousand to 14 per thousand. The entry rate has not increased as fast in rural China as it has in urban China.

\footnotetext{
${ }^{9}$ Cadre status is coded slightly differently for the urban and rural samples. For the urban sample, I code those who reported their occupation as "middle-rank manager/ administrator" and "highrank manager/administrator," or that their position at the rank of section chief ( $g u j i)$, as "cadre"; rural cadre includes both township cadre and village cadre, which are directly reported by respondents.
} 


\section{Temporal Trend of Entry into Self-Employment}

Table 4 presents estimated discrete-time logit models for the urban and rural samples, separately. Education, political capital (combination of party membership and cadre status), age, gender, parent's self-employment status, and parent's party membership are included as independent variables. To gauge the temporal variations of entry rate, reform phases are included as two dummy variables in the models. Results in Models 1 and 2 are consistent with those observed in Table 2. In urban China, both education and political capital deter workers from entering selfemployment (Model 1). The effect of education on the rate of entry appears to be concave, first increasing then diminishing after reaching 4.4 years of schooling. Since most urban workers have completed more than 4.4 years of education, essentially the rate is negatively associated with education. Model 2 also shows a concave relationship between education and the rate of entry in rural China. Taking the first derivative of the equation in Model 2 and solving it, I obtain 9.1 years as the optimal value of schooling. However, since most rural workers have few than 9 years of education, education among rural workers indeed promotes the entry into selfemployment. Hypothesis 2 is thus re-confirmed with the event history data.

As predicted by Hypotheses $3 a$ and 3b, the net odds of self-employment for ordinary party members are only 26 percent $\left(=\mathrm{e}^{-1.356}\right)$ of those for ordinary workers, and the net odds of entry for cadres are only 15 percent $\left(=\mathrm{e}^{-1.929}\right)$ of those for ordinary workers in urban China. In rural China, however, neither party membership nor cadre status has a significant effect on selfemployment entry. 
Table 3. Selected Characteristics for Self-Employment Entrants: Rural and Urban China (1978-1996)

\begin{tabular}{|c|c|c|c|c|c|c|c|c|c|c|c|}
\hline & $\begin{array}{l}\text { Entry } \\
\text { Rate }\end{array}$ & $\begin{array}{c}\text { Mean } \\
\text { schooling }\end{array}$ & $\begin{array}{l}\text { College } \\
\text { or above }\end{array}$ & $\begin{array}{c}\text { Ordinary } \\
\text { Worker }\end{array}$ & $\begin{array}{c}\text { Ordinary } \\
\text { party } \\
\text { member }\end{array}$ & Cadre & $\begin{array}{c}\text { Mean } \\
\text { Age }\end{array}$ & Male & $\begin{array}{c}\text { Parent in } \\
\text { market }\end{array}$ & $\begin{array}{c}\text { Parent } \\
\text { party } \\
\text { member }\end{array}$ & $\begin{array}{l}\# \text { of } \\
\text { events }\end{array}$ \\
\hline \multicolumn{12}{|c|}{ Entry into self-employment } \\
\hline Overall & 0.67 & 7.9 & 2.5 & 95.1 & 2.6 & 2.3 & 29.5 & 59.5 & 6.8 & 16.6 & 602 \\
\hline Phase I (1978-1986) & 0.50 & 7.4 & 1.0 & 94.8 & 3.8 & 1.4 & 27.0 & 67.6 & 9.2 & 15.0 & 207 \\
\hline Phase II (1987-1991) & 0.71 & 7.8 & 1.8 & 95.5 & 2.2 & 2.2 & 29.8 & 58.8 & 5.1 & 17.5 & 177 \\
\hline Phase III (1992-1996) & 0.93 & 8.4 & 4.4 & 95.0 & 1.8 & 3.2 & 31.6 & 52.3 & 6.0 & 17.4 & 218 \\
\hline Urban & 0.92 & 8.2 & 3.2 & 95.1 & 2.5 & 2.5 & 30.8 & 54.3 & 8.0 & 17.6 & 398 \\
\hline Phase I (1978-1986) & 0.59 & 7.6 & 0.9 & 94.2 & 5.0 & 0.8 & 29.1 & 61.3 & 13.4 & 16.0 & 119 \\
\hline Phase II (1987-1991) & 1.04 & 8.1 & 2.5 & 96.1 & 0.8 & 3.1 & 30.5 & 56.8 & 5.6 & 17.6 & 125 \\
\hline Phase III (1992-1996) & 1.40 & 8.6 & 5.5 & 94.8 & 1.9 & 3.2 & 32.4 & 46.8 & 5.8 & 18.8 & 154 \\
\hline Rural & 0.44 & 7.3 & 1.1 & 95.0 & 3.0 & 2.0 & 26.9 & 69.6 & 4.4 & 14.7 & 204 \\
\hline Phase I (1978-1986) & 0.41 & 7.2 & 1.2 & 95.5 & 2.2 & 2.2 & 24.3 & 76.1 & 3.4 & 13.6 & 88 \\
\hline Phase II (1987-1991) & 0.40 & 6.9 & 0.0 & 94.0 & 6.0 & 0.0 & 28.1 & 63.5 & 3.8 & 17.3 & 52 \\
\hline Phase III (1992-1996) & 0.52 & 7.7 & 1.7 & 95.2 & 1.6 & 3.2 & 29.6 & 65.6 & 6.3 & 14.1 & 64 \\
\hline
\end{tabular}


Table 4: Coefficient Estimates for Discrete-Time Hazard Models on Self-Employment Entry: Rural and Urban China (1978-1996)

\begin{tabular}{|c|c|c|}
\hline Time-dependent variable & $\frac{\text { Urban }}{\text { Model } 1}$ & $\frac{\text { Rural }}{\text { Model } 2}$ \\
\hline $\begin{array}{l}\text { Education } \\
\text { Education square }\end{array}$ & $\begin{array}{l}0.106^{*} \\
(0.046) \\
-0.012 * * * \\
(0.003)\end{array}$ & $\begin{array}{l}0.326^{* *} \\
(0.116) \\
-0.018^{*} \\
(0.008)\end{array}$ \\
\hline $\begin{array}{l}\text { Political capital [ordinary wo } \\
\text { Ordinary party member } \\
\text { Cadre }\end{array}$ & $\begin{array}{l}-1.356^{* * *} \\
(0.318) \\
-1.929^{* * *} \\
(0.516)\end{array}$ & $\begin{array}{c}0.057 \\
(0.482) \\
0.609 \\
(0.537)\end{array}$ \\
\hline Age & $\begin{array}{l}-0.044 * * * \\
(0.006)\end{array}$ & $\begin{array}{l}-0.047 * * * \\
(0.012)\end{array}$ \\
\hline $\begin{array}{l}\text { Time-independent variable } \\
\text { Male }\end{array}$ & $\begin{array}{l}0.436^{* *} \\
(0.106)\end{array}$ & $\begin{array}{l}0.612 * * * \\
(0.158)\end{array}$ \\
\hline Parent self-employed & $\begin{array}{l}0.630 * * \\
(0.217)\end{array}$ & $\begin{array}{c}1.011^{*} \\
(0.420)\end{array}$ \\
\hline Parent party member & $\begin{array}{r}-0.334^{*} \\
(0.169)\end{array}$ & $\begin{array}{c}0.092 \\
(0.219)\end{array}$ \\
\hline \multicolumn{3}{|c|}{ REFORM PHASE (PHASE I [1978-1986] OMITTED) } \\
\hline Reform Phase II: 1987-1991 & $\begin{array}{l}0.786^{* * *} \\
(0.172)\end{array}$ & $\begin{array}{l}-0.015 \\
(0.198)\end{array}$ \\
\hline Reform Phase III: 1992-1996 & $\begin{array}{l}1.157^{* * *} \\
(0.214)\end{array}$ & $\begin{array}{l}0.527 * * * \\
(0.158)\end{array}$ \\
\hline Constant & $\begin{array}{l}-3.799 * * * \\
(0.323)\end{array}$ & $\begin{array}{l}-5.794 * * * \\
(0.574)\end{array}$ \\
\hline $\begin{array}{l}\chi^{2} \\
\text { Degree of freedom }\end{array}$ & $\begin{array}{c}246.8 \\
10\end{array}$ & $\begin{array}{l}79.5 \\
10\end{array}$ \\
\hline $\begin{array}{l}\text { \# of events } \\
\text { Person-year at risk }\end{array}$ & $\begin{array}{r}398 \\
47814\end{array}$ & $\begin{array}{r}204 \\
50710\end{array}$ \\
\hline
\end{tabular}

Notes: Figures in parentheses are standard errors adjusted for clustering on counties. Data are weighted. $* * * \mathrm{p}<.001 * * \mathrm{p}<.01 * \mathrm{p}<.05 \dagger \mathrm{p}<.10$ (two-tailed tests). 
Consistent with Hypothesis 4, the likelihood of entry also increases with the development of marketization. In urban China, the net odds of entry increase $2.2\left(=\mathrm{e}^{0.786}\right)$ times in the second phase of reform and $3.2\left(=\mathrm{e}^{1.157}\right)$ times in the third phase $(p<.001)$. In rural China, the net odds of entry did not increase between the first two phases (1978-1986 and 1987-1991), but increased by 68 percent $\left(=e^{0.527}-1\right)$ in the third phase.

T-tests show that both coefficients for reform phases in Model 1 are significantly greater than the corresponding ones in Model 2, suggesting that the rural-urban gap in self-employment has enlarged with marketization and given urban workers disproportionate access to these growing market opportunities.

\section{The Changing Role of Human Capital and Political Capital}

As economic reform has accelerated since the mid-1980s in urban China, how have workers used their human capital and political capital in response to the expanding market opportunities? In this section I examine how the role of human capital (education) and political capital (party membership and cadre status) varies across different phases of economic reform in determining entry into self-employment.

In Table 5, I first fit an additive model for the urban sample (Model 1a), then add the interaction terms of both education and political capital with reform phase (Model 2a). Since college credentials are particularly advantageous to career mobility in post-Mao China (Walder, Li and Treiman 2000), it is revealing to learn how college graduates, who would also have a bright future in the state sector, respond to the expanding market opportunities. For this reason I code education as a dummy variable (college graduate $=1$ ).

In Model 1a, all independent variables are significant predictors of entry into selfemployment. College graduates are less likely to enter self-employment in urban China. The net odds of entry into self-employment for college graduates are only 45 percent $\left(=\mathrm{e}^{-0.789}\right)$ of those 
for non-college graduates. Other independent variables operate similarly to those in Model 1 of Table 4.

In Model 2a of Table 5, the interaction terms of reform phases with both college education and political capital are introduced for the urban sample. The positive coefficients for the interaction terms between college education and reform phases suggest that, while college graduates are still less likely than non-college graduates to become self-employed, they are more likely to do so in the second and third phases of reform than in the first phase. As Table 3 shows, college graduates account for only 0.9 percent of all self-employment entrants in the first phase, but the percentage has increased to 2.5 in the second phase and further to 5.5 in the third phase. After adjusting for other variables in Model 2a, the net odds of entry into self-employment for college graduates are only 11 percent $\left(=\mathrm{e}^{-2.222}\right)$ of the net odds for workers with no college education in the first phase. This figure increases to 38 percent $\left(=\mathrm{e}^{-2.222+1.260}\right)$ in the second phase and 59 percent $\left(=\mathrm{e}^{-2.222+1.686}\right)$ in the third phase. The increase from the first phase to the third phase is marginally significant $(p<.10)$, lending some support to Hypothesis 5 , which posits that with the development of reform, the likelihood of entry into self-employment will increase for higher educated people.

Hypothesis 6a posits that party membership will have an effect similar to education: as the reform proceeds, party members will be increasingly more likely to become self-employed. However, Model 2a suggests the opposite: throughout the three phases, ordinary party members are decreasingly less likely to become self-employed relative to ordinary workers. In urban China, the net odds of self-employment for an ordinary party member are 68 percent $\left(=\mathrm{e}^{-0.387}\right)$ of the net odds for an ordinary worker in the first phase, other things being 
William Davidson Institute Working Paper 512

Table 5: Coefficient Estimates for Discrete-Time Hazard Models on Self-Employment Entry: Urban and Rural China (1978-1996)

\begin{tabular}{|c|c|c|c|c|}
\hline \multirow[b]{2}{*}{ Time-dependent Variables } & \multicolumn{2}{|c|}{ Urban } & \multicolumn{2}{|c|}{ Rural } \\
\hline & Model $1 \mathrm{a}$ & Model 2a & Model 1b & Model 2b \\
\hline College or above & $\begin{array}{l}-0.789 * \\
(0.337)\end{array}$ & $\begin{array}{l}-2.222^{*} \\
(0.974)\end{array}$ & $\begin{array}{l}1.131 \dagger \\
(0.346)\end{array}$ & $\begin{array}{l}2.100^{* *} \\
(0.795)\end{array}$ \\
\hline \multicolumn{5}{|l|}{$\begin{array}{l}\text { Political capital } \\
\text { [ordinary worker omitted] }\end{array}$} \\
\hline Ordinary party member & $\begin{array}{l}-1.394 * * * \\
(0.314)\end{array}$ & $\begin{array}{l}-0.387 \\
(0.379)\end{array}$ & $\begin{array}{l}0.205 \\
(0.491)\end{array}$ & $\begin{array}{c}0.187 \\
(0.778)\end{array}$ \\
\hline Cadre & $\begin{array}{l}-2.016 * * * \\
(0.513)\end{array}$ & $\begin{array}{l}-3.937 * * * \\
(1.004)\end{array}$ & $\begin{array}{c}0.767 \\
(0.545)\end{array}$ & $\begin{array}{c}0.968 \\
(0.791)\end{array}$ \\
\hline Age & $\begin{array}{l}-0.040 * * * \\
(0.005)\end{array}$ & $\begin{array}{l}-0.039 * * * \\
(0.005)\end{array}$ & $\begin{array}{l}-0.058 * * * \\
(0.012)\end{array}$ & $\begin{array}{l}-0.058 * * * \\
(0.012)\end{array}$ \\
\hline \multicolumn{5}{|l|}{ Time-Independent Variables } \\
\hline Male & $\begin{array}{l}0.408 * * * \\
(0.109)\end{array}$ & $\begin{array}{l}0.408 * * * \\
(0.109)\end{array}$ & $\begin{array}{l}0.817 * * * \\
(0.171)\end{array}$ & $\begin{array}{l}0.820 * * * \\
(0.171)\end{array}$ \\
\hline Parent self-employed & $\begin{array}{l}0.665^{*} \\
(0.216)\end{array}$ & $\begin{array}{c}0.666^{*} \\
(0.215)\end{array}$ & $\begin{array}{l}1.065^{*} \\
(0.426)\end{array}$ & $\begin{array}{l}1.065^{*} \\
(0.428)\end{array}$ \\
\hline Parent in market & $\begin{array}{r}0.665^{*} \\
(0.216)\end{array}$ & $\begin{array}{r}0.666^{*} \\
(0.215)\end{array}$ & $\begin{array}{l}1.065^{*} \\
(0.426)\end{array}$ & $\begin{array}{l}1.065^{*} \\
(0.428)\end{array}$ \\
\hline Parent party member & $\begin{array}{l}-0.428^{*} \\
(0.177)\end{array}$ & $\begin{array}{l}-0.434 * \\
(0.178)\end{array}$ & $\begin{array}{c}0.117 \\
(0.228)\end{array}$ & $\begin{array}{c}0.188^{*} \\
(0.228)\end{array}$ \\
\hline Phase II: 1987-1991 & $\begin{array}{l}0.753 * * * \\
(0.186)\end{array}$ & $\begin{array}{l}0.778 * * * \\
(0.164)\end{array}$ & $\begin{array}{c}0.073 \\
(0.193)\end{array}$ & $\begin{array}{c}0.077 \\
(0.200)\end{array}$ \\
\hline Phase III: 1992-1996 & $\begin{array}{l}1.090^{* * *} \\
(0.212)\end{array}$ & $\begin{array}{l}1.086^{* * *} \\
(0.205)\end{array}$ & $\begin{array}{l}0.669 * * * \\
(0.143)\end{array}$ & $\begin{array}{l}0.698^{* * *} \\
(0.131)\end{array}$ \\
\hline \multicolumn{5}{|l|}{ Interaction Terms } \\
\hline College or above * Phase II & - & $\begin{array}{l}1.260 \\
(0.806)\end{array}$ & - & - \\
\hline College or above * Phase III & - & $\begin{array}{r}1.686 \dagger \\
(0.985)\end{array}$ & - & $\begin{array}{l}-1.212 \\
(1.468)\end{array}$ \\
\hline Non-cadre party member* Phase II & - & $\begin{array}{l}-2.304 * \\
(1.094)\end{array}$ & - & $\begin{array}{c}0.700 \\
(1.017)\end{array}$ \\
\hline Non-cadre Party member * Phase III & - & $\begin{array}{l}-1.661^{*} \\
(0.657)\end{array}$ & - & $\begin{array}{l}-0.804 \\
(1.257)\end{array}$ \\
\hline Cadre * Phase II & - & $\begin{array}{l}2.139^{*} \\
(1.055)\end{array}$ & - & - \\
\hline Cadre* Phase III & - & $\begin{array}{l}2.566^{* *} \\
(0.997)\end{array}$ & - & $\begin{array}{c}0.118 \\
(1.254)\end{array}$ \\
\hline Constant & $\begin{array}{l}-3.966^{* * *} \\
(0.221)\end{array}$ & $\begin{array}{l}-3.982 * * * \\
(0.215)\end{array}$ & $\begin{array}{l}-4.526^{* * * *} \\
(0.348)\end{array}$ & $\begin{array}{l}-4.535^{* * *} \\
(0.351)\end{array}$ \\
\hline$\chi^{2}$ & 195.5 & 747.6 & 101.3 & 120.7 \\
\hline Degree of Freedom & 9 & 15 & 9 & 13 \\
\hline Number of Events & \multicolumn{2}{|c|}{398} & \multicolumn{2}{|c|}{204} \\
\hline
\end{tabular}

Notes: Figures in parentheses are standard errors adjusted for clustering on counties. Data are weighted. $* * * \mathrm{p}<.001 * * \mathrm{p}<.01 * \mathrm{p}<.05 \dagger \mathrm{p}<.10$ (two-tailed tests) 
equal, but are only 7 percent $\left(=\mathrm{e}^{-0.387-2.304}\right)$ in the second phase $(p<.10)$, and 15 percent $\left(=\mathrm{e}^{-0.387-}\right.$ $\left.{ }^{1.661}\right)$ in the third phase $(p<.05)$.

However, both estimated coefficients for the interaction terms between cadre status and reform phases are positive $(p<.05)$, suggesting that cadres are increasingly more likely to become self-employed in later phases of the reform. The net odds of entry for a cadre member are only 2 percent $\left(=\mathrm{e}^{-3.937}\right)$ of the net odds for an ordinary worker in the first phase, but increase to 16 percent $\left(=\mathrm{e}^{-3.937+2.139}\right)$ in the second phase, and to 25 percent $\left(=\mathrm{e}^{-3.937+2.566}\right)$ in the third phase. These findings strongly support Hypothesis $6 \mathrm{~b}$, which predicts the temporal increase in the likelihood of entry into self-employment for cadres.

To contrast transition dynamics in rural China with those for urban China, the above models are replicated in Models $1 b$ and $2 b$ for the rural sample. In Model $2 b$, none of the interaction terms has reached the level of statistical significance. In other words, the effects of college education, party membership, and cadre status on entry into self-employment do not vary in the course of market transition.

\section{SUMMARY AND CONCLUSIONS}

This paper introduces labor market transitions as a mediating process by which the macro institutional transition to a market economy alters social stratification outcomes. Rather than directly examining income determination, I studied patterns and determinants of Chinese workers' entry into self-employment. Analyses of the work history data from a national representative survey show that while rural and urban workers in China are similar in some regards to one another (and to workers in other countries) in their patterns of entry into selfemployment, they also differ substantially in other key aspects. 
Contrary to Hypothesis 1, the rate of entry into self-employment is lower for rural workers than for urban workers. Furthermore, this gap seems to be broadened as marketization proceeds. While the entry rate increases across different reform phases in both rural and urban China (Hypothesis 4), it grows much faster in urban China than in rural China, especially in the late reform phase, suggesting that urban workers are increasingly more likely to take advantage of the expanding market opportunities for entrepreneurial activities. ${ }^{10}$

Concerning the roles of human capital and political capital in labor market transitions, rural and urban China present almost diametrical patterns. While education promotes rural workers' entry into self-employment, it deters urban workers' entry (Hypothesis 2); and while both party membership and cadre status significantly reduce urban workers' involvement in selfemployment (Hypotheses 3a and 3b), neither has an effect on entry for rural workers.

The roles played by human capital and political capital in labor market transitions are contingent on the phase of the reform process as well. Although in urban China college graduates are still less likely to be involved in self-employment than non-college graduates in all three reform phases, they are increasingly more likely to do so in the later phases of reform. In rural China college graduates are more likely than non-college graduates to become self-employed, and this rate remains constant in all phases of reform (Hypothesis 5).

In urban China, ordinary party members are found less likely to be involved in selfemployment than ordinary workers, and become even less likely to do so in later phases (Hypothesis 6a). However, cadres, though appear to be less likely to be involved in self-

\footnotetext{
${ }^{10}$ This process is actually consistent with the observed trend in urban-rural inequality in income per capita (an important stratification outcome) in reform-era China. In the early reform phase the urban/rural ratio of per capita income decreased from 2.35 in 1978 to 2.14 in 1985. However, as the reform shifted to urban areas in the mid-1980s, in the later phase the ratio increased from 2.40 in 1986 to 2.79 in 1995 (SSB 1986, 1996).
} 
employment than ordinary workers, become increasingly more likely to do so over the course of market transition (Hypothesis 6b). Thus, results regarding the influence of political capital in labor market transition are mixed.

In the literature on socialist and post-socialist stratification, both party membership and cadre status are commonly used to denote political influence. However, their implications for social stratification are different. While a political credential (party membership) may lead to cadre/administrative status, redistributive power is intrinsically associated with the latter rather than the former. In the process of transition to self-employed entrepreneurs, former cadres can utilize the positional power they used to have to help them acquire new advantages in the market. Thus the thesis of "power conversion" to some extent is supported by evidence from urban China.

Neither market nor state employment alone has inherent implications for social stratification outcomes (Walder 2002; Wu and Xie 2002). The variety of scenarios for entry into self-employment suggests that the process and social consequence of transition toward a market economy are far more complicated, depending upon concrete institutional parameters that differ between rural and urban areas, and vary from phase to phase of the reform. Empirical findings based on a segment of a society or a specific reform phase under certain conditions cannot be generalized beyond those conditions. Without specifying the scope conditions, any grand theory on the change of post-socialist stratification would necessarily cause controversies.

\section{DISCUSSION: A SYNTHESIS ON SOCIAL OUTCOMES OF THE MARKET TRANSITION}

The growing employment in the market sector is an important chapter of the transition from redistribution to markets. What distributional consequences has the labor market transition brought about? As of 1996, 13.5 percent of urban workers and 7.5 percent of rural workers have 
been involved in self-employed activities (see Table 1); Self-employed workers earn twice as much as non-self-employed workers in urban China, and three times as much as non-selfemployed workers in rural China. ${ }^{11}$ Putting this in the perspective of the ISEI (International Socioeconomic Status Index) score, entry into self-employment increases one's socioeconomic status by 10 in China. Regardless of whether they are individual business owners, private entrepreneurs, or corporate entrepreneurs, self-employed workers in China generally can be seen as the main beneficiary of the market transition. ${ }^{12}$

Given this fact, the variations in patterns of entry into self-employment in different contexts may help to reconcile some controversies in the market transition debate, even though the direct link between labor market transition and its distributional outcome is yet subject to empirical tests. Once the concrete institutional environments are specified, indeed there is little disagreement among the parties involved the debate. Each has captured only part of the story in the market transition.

\footnotetext{
${ }^{11}$ Self-employed workers' monthly income is computed based on their household annual income (divided by the number of working family members and 12 months). The average monthly income is 970 RMB Yuan for urban self-employed workers and 604 RMB Yuan for rural selfemployed workers, while the average monthly income is 496 RMB Yuan for urban non-selfemployed workers and $240 \mathrm{RMB}$ Yuan for rural non-self-employed workers. Even after adjusting education, age, gender, and region, the income advantage of self-employed workers is still quite big.

${ }^{12}$ Hanley (2000) pointed out that the body of self-employed workers in post-communist Eastern Europe (Czech Republic, Poland and Slovakia) is heterogeneous, encompassing both the individually self-employed and the employers. The former differ little in socioeconomic status from ordinary workers, while the later receive incomes and possess assets far in excess of those of both the individually self-employed and ordinary workers. Closely reading the Table presented in his paper, I found that in the two of the three countries (Czech Republic and Slovakia), the individually self-employed still enjoy significant income advantages over ordinary workers. In post-communist Russia, Gerber (2001) concluded that the self-employed workers with employees and without employees both are winners in the transition in post-communist Russia.
} 
One of the controversies in the market transition debate (AJS Symposium 1996) is how to explain the U-shape trajectory of income distribution — that is, the decline in inequality during the early reform phase followed by an increase - in all former state socialism countries. Some argue that the decline of income inequality results from the state egalitarian policy designed to win support of the working class for the reform (Bian and Logan 1996); others believe that the initial decline is due to the emergence of new market opportunities (Nee 1989; Szelenyi 1978). My findings have provided some evidence of how the market could serve as an equalizing mechanism in social stratification in early reform. As shown in these analyses, early entrants to self-employment tended to be those from low tiers of the redistributive hierarchy (i.e., rural peasants or urban lower-class workers) who were able to increase income and living standards through entrepreneurial activities. Consequently, socioeconomic inequality between urban and rural areas, and within urban areas, decreased in the initial phase of reform (see note 10).

This equalizing effect of the market, however, vanished in later phases. Since the mid1980s urban workers in China have been increasingly more likely than rural workers to be engaged in entrepreneurial activities; and within urban areas, more skilled workers from the state sector started entering the market too. Equipped with higher levels of human and political capital, these later comers pushed early entrants to marginal positions in market competition. A recent study by Wu and Xie (2002) found that by 1996 early entrants to the market in China no longer enjoyed income advantages and returns to education over workers who stayed in the urban state sector.

The transition scenario in rural China described here is also consistent with market transition theory: human capital (education) increases the chance of entry into self-employment, whereas political attributes have no significant impact on access to the lucrative market 
opportunities. However, these claims can hardly be true beyond the rural context. ${ }^{13}$ In urban China, education and political attributes actually deter entry into self-employment: lower educated workers are more likely to participate in market activities because, compared to their better-educated counterparts, they are much more likely to increase their income by switching from the state sector. In a certain period of transition, urban China once experienced a decrease in both income inequality and returns to education. ${ }^{14}$ This phenomenon in China has been phrased as the "unfairness" of income distribution (shouru feipei bugong), a major social problem that led to wide discontent in the later 1980s (Li 1987; Zhou and Tan 1996; Zhao 1993).

Perhaps the greatest challenge to market transition theory in the debate is the thesis of “power conversion” (Hankiss 1990; Rona-Tas 1994; Staniszkis 1991). In post-1989 Eastern Europe after the collapse of communist regimes, former cadres were found to have successfully converted past political power to new economic advantage (Rona-Tas 1994). In urban China, while cadres are still less likely than ordinary workers to enter self-employment, they were found to be increasingly more likely to do so in the later phase of reform-evidence supporting the ongoing process of "power conversion."

Returning to the fundamental question on post-socialist social stratification: Who will be the ultimate winners and losers in China's transition? While the transition process is not yet completed, the answer is quite clear. In the later phase of reform, the entry into self-employment

\footnotetext{
${ }^{13}$ The theory was originally formulated based on the data from rural Fujian Province in 1985. No later analyses of the data from urban China have confirmed Nee's original claims.

${ }^{14}$ In an analysis of the 1988 urban income survey data, Xie and Hannum (1996) found that returns to education decline as the marketization proceeds, based on which they challenged the applicability of Nee's market transition theory in urban context. Wu (2002) examined the role of work units in income distribution and presented a tentative explanation of the decline in returns to education in urban China.
} 
for both college graduates and former cadres has been accelerated. Once they embrace the market, those on the top in the state socialist system will be able to maintain their advantages. As Szelenyi and Kostello (1996:1094) conclude: "as a new social order settles, it is likely that those who are on the top will find themselves able to maintain that position, and those at the bottom will end up on staying there as well. Change is the exception and reproduction that rule of social orders, be they communist or capitalist." 


\section{REFERENCES}

Allison, Paul. 1982 "Discrete-Time Methods for the Analysis of Event Histories." Pp 61-98 in Sociological Methodology 1982, edited by S. Leihnardt, San Francisco, CA: Jossey-Bass.

Bian, Yanjie. 1994. Work and Inequality in Urban China. Albany: State University of New York Press.

Bian, Yanjie and John Logan. 1996. "Market Transition and Persistence of Power: The Changing Stratification System in Urban China." American Sociological Review 61: 739-758.

Borjas, G.J., and S. G. Bronars. 1989. "Consumer Discrimination and Self-employment.” Journal of Political Economy 97:581-605.

Cao, Yang, and Victor Nee. 2000. "Comment: Controversies and Evidence in the Market Transition Debate" American Journal of Sociology 105:1175-89.

Carr, Deborah. 1996. "Two Paths to Self-employment? Women's and Men's Self-employment in the United States, 1980." Work and Occupations 23:26-53.

Chen, Ruying (edits) 1993. Xiahai Kuangchao (The Surging Wave of Jumping into the Sea). Beijing: Tuanjie Press. [in Chinese]

Davis, Deborah 1999. "Self-employment in Shanghai: A Research Note." The China Quarterly 157: 22-43.

Evans, David S. and Linda S. Leighton. 1989. "Some Empirical Aspects of Entrepreneurship." American Economic Review 79:519-35.

Fuchs, V. 1980. "Self-employment and Labor Force Participation of Old Males." NBER Working Paper No. 584. Cambridge, MA: National Bureau of Economic Research.

Gerber, Theodore and Michael Hout 1998. "More Shock than Therapy: Employment and Income in Russia, 1991-1995." American Journal of Sociology 104:1-50.

Gerber, Theodore. 1999. "Membership Benefits or Selection Effects? Why Former Communist Party Members Do Better in Post-Soviet Russia." Social Science Research 29:25-50.

2000. "Membership Benefits or Selection Effects? Why Former Communist Party Members Do Better in Post-Soviet Russia. ”Social Science Research 29:25-50. 
2001. "Paths to Success: Individual and Regional Determinants of Self-employment Entry in Post-Communist Russia." International Journal of Sociology 31 (2) 3-37.

2003. "Structural Change and Post-Socialist Stratification: Labor Market Transitions in Contemporary Russia." American Sociological Review (forthcoming).

Gold, Thomas. 1991. "Urban Private Business and Social Change” Pp157-180 in Chinese Society on the Eve of Tiananmen: the Impact of Reform, edited by Deborah Davis and Ezra Vogel, Council on East Asian Studies, Harvard University.

Griffin, Keith and Renwei Zhao. 1993. The Distribution of Income in China. London: Macmillan.

Guthrie, Douglas. 1997. "Between Markets and Politics: Organizational Response to Reform in China." American Journal of Sociology 102:1258-304.

Hankiss, Elemer. 1990. East European Alternatives. Oxford: Clarendon Press.

Hanley, Eric. 2000. "Self-Employment in Post-Communist Eastern Europe: a Refuge from Poverty or Road to Riches." Communist and Post-Communist Studies 33:379-402.

Hauser, Seth and Yu Xie. 2001. "Temporal and Regional Variation in Earnings Inequality: Urban China in Transition between 1988 and 1995." Paper presented in semiannual meeting of the International Sociology Association Research Committee on Social Stratification (RC28), Berkeley, August 2001.

Kornai, Janos. 1992. The Socialist System: The Political Economy of Communism. Princeton University Press.

Li, Qiang. 1993. Dangdai Zhongguo de Shehui Fenceng Yu Liudong.(Social Stratification and Mobility in Contemporary China). Beijing: China Economy Press. [in Chinese].

Li, Qiang, and Dayong Hong 1995. Shichang Jinji, Fazhan Chaju Yu Shehui Gongping (Market Economy, Development Gap, and Social Equity). Harbin: Heilongjiang Renmin Press. [in Chinese].

Lin, Nan. 1995. "Local Market Socialism: Local Corporatism in Action.” Theory \& Society 24:301-54. 
Lin, Nan and Yanjie Bian. 1991. "Getting Ahead in Urban China." American Journal of Sociology 97:657-88.

Luber, Silvia, Henning Lohmann, Walter Muller, and Paolo Barbieri. 2001. "Male SelfEmployment in Four European Countries: The Relevance of Education and Experiences across Industries." International Journal of Sociology 30(3):5-44.

Nee, Victor. 1989a. "A Theory of Market Transition: From Redistribution to Markets in State Socialism." American Sociological Review 54: 663-81.

1989b "Peasant Entrepreneurship and the Politics of Regulation in China" pp 169-207 in Remaking the Economic Institutions in Socialism: China and Eastern Europe. Edited by Victor Nee and David Stark. Stanford University Press.

1991. "Social Inequalities in Reforming State Socialism: Between Redistribution to Markets in China." American Sociological Review 56:267-82.

1992. "Organizational Dynamics of Market Transition: Hybrid Forms, Property Rights, and Mixed Economy in China.” Administrative Science Quarterly 37:1-27.

1996. "The Emergence of a Market Society: Changing Mechanisms of Stratification in China." American Journal of Sociology 101:908-49.

Nee, Victor and Peng Lian 1994. "Sleeping with the Enemy: A Dynamic Model of Declining Political Commitment in State Socialism." Theory and Society 23(3): 253-96.

Nee, Victor and Rebecca Matthews.1996. "Market Transition and Societal Transformation in Reforming State Socialism." Annual Review of Sociology 22:401-435.

Nee, Victor and Yang Cao, 1999. "Path Dependent Societal Transformation: Stratification in Hybrid Mixed Economies." Theory and Society 28:799-834.

North, Douglas. 1990. Institutions, Institutional Change, and Economic Performance. Cambridge University Press.

Oi, Jean C. 1990. "The Fate of the Collective after the Commune" Pp. 15-36 in Chinese Society on the Eve of Tiananmen: the Impact of Reform, edited by Debra Davis and Ezra Vogel, Council on East Asian Studies, Harvard University. 
Oberschall, Anthony. 1996. "The Great Transition: China, Hungary, and Sociology Exit Socialism into the Market.” American Journal of Sociology 101:1028-41.

Parish, William L. 1984. "Destratification in China." Pp.84-120 in Class and Social Stratification in Post-revolution China, edited by J. Watson. New York: Cambridge Univ. Press.

Parish, William L. and Ethan Michelson. 1996. "Politics and Markets: Dual Transformations." American Journal of Sociology 101:1042-59.

Parish, William L. and Martin King Whyte 1978. Village and Family in Contemporary China Chapter 4 "Collective Agricultural Organization" Pp30-43. The University of Chicago Press.

Pei, Minxin 1996. "Micro-foundations of State-socialism and Patterns of Economic Transformation" Communist and Post-Communist Studies 29(2):131-45.

Peng, Yusheng. 1992. "Wage Determination in Rural and Urban China: A Comparison of Public and Private Industrial Sectors.” American Sociological Review 157: 198-213.

2001. "Chinese Villages and Townships as Industrial Corporations: Ownership, Governance, and Market Discipline.”American Journal of Sociology 106:1338-70.

Powers, Daniel and Yu Xie 2000. Statistical Methods for Categorical Data Analysis. New York: Academic Press.

Qian, Yingyi. 1999. “The Process of China's Market Transition (1978-98): The Evolutionary, Historical, and Comparative Perspectives." Paper prepared for the Journal of Institutional and Theoretical Economics symposium on "Big-Bang Transformation of Economic Systems as a Challenge to New Institutional Economics.” June 9-11, 1999, Wallerfangen/Saar, Germany.

Robert, Peter, and Erszebet Bukodi. 2000. "Who are the Entrepreneurs and Where do They Come From? Transition top Self-employment Before, Under, and After Communism in Hungary." International Review of Sociology 10:147-71.

Rona-Tas, Akos. 1994. "The First Shall Be Last? Entrepreneurship and Communist Cadre in the Transition From Socialism." American Journal of Sociology 100:40-69. 
SSB (State Statistical Bureau), PRC. 1986. China Statistical Yearbook. Beijing: China Statistical Publishing House.

1996. China Statistical Yearbook. Beijing: China Statistical Publishing House.

.1998. China Labor Statistics Book 1997. Beijing: China Statistics Publishing House.

Staniszkis, Jadwiga. 1991. The Dynamics of the Breakthrough in Eastern Europe: The Polish Experience. University of California Press.

Stark, David. 1989. "Coexisting Organizational Forms in Hungary's Emerging Mixed Economy." Pp. 137-168 in Remaking the Economic Institutions of Socialism: China and Eastern Europe, edited by Victor Nee and David Stark. Stanford University Press.

. 1992. "Path Dependence and Privatization Strategies in East and Central Europe." East European Politics and Societies 6:17-51.

. 1996. "Recombinant Property in East Europe Capitalism" American Journal of Sociology 101:993-1027.

Stark, David, and Victor Nee. 1989 “Toward an Institutional Analysis of State Socialism." Pp. 1-31 in Remaking the Economic Institutions of Socialism: China and Eastern Europe, edited by Victor Nee and David Stark. Palo Alto, Calif.: Stanford University Press.

Stata Corp. 2001. Stata Reference Manual: Volume 3, Stata Corporation. College Station, Texas.

Szelenyi, Ivan. 1978. "Social Inequalities in State Socialist Redistributive Economies." International Journal of Comparative Sociology 19:63-87.

1983. Urban Inequalities under State Socialism. Oxford: Oxford University Press.

1988. Socialist Entrepreneurs. Madison: University of Wisconsin Press.

1989. "Eastern Europe in an Epoch of Transition: Toward a Socialist Mixed Economy?" Pp 208-232 in Remaking the Economic Institutions in Socialism: China and Eastern Europe. Edited by Victor Nee and David Stark. Stanford University Press.

Szelenyi, Ivan, and Eric Kostello. 1996. "The Market Transition Debate: Toward a Synthesis." American Journal of Sociology 101:1082-96. 
Treiman, Donald J. 1998. The Code Bookfor Chinese Life History Survey. ISSR UCLA.Vogel, Erza. 1989. One Step Ahead in China: Guangdong under Reform. Harvard University Press.

Walder, Andrew G. 1986. Communist Neo-Traditionalism: Work and Authority in Chinese Industry. University of California Press.

1990. "Economic Reform and Income Distribution in Tianjin, 1976-1986." Pp.135-56 in Chinese Society on the Eve of Tiananmen: the Impact of Reform. edited by Deborah Davis and Ezra F. Vogel. Cambridge MA: Harvard.

1992 "Property Rights And Stratification in Socialist Redistributive Economics." American Sociological Review 57:524-39.

1995 "Local Governments as Industrial Firms: An Organizational Analysis of China's Transitional Economy” American Journal of Sociology 101:263-301.

1996. "Markets and Inequality in Transitional Economics: Toward Testable Theories." American Journal of Sociology 101:1060-73.

2002. "Markets, Economic Growth, and Inequality in Rural China in the 1990s." American Sociological Review 67:231-253.

Walder, Andrew, Bobai Li, and Donald Treiman 2000. "Politics and Life Chances in a State Socialist Regime: Dual Career Paths into the Urban Chinese Elite, 1949-1996." American Sociological Review (April): 191-209.

Wang, Xiujie. 2001. "Zhongguo Siying Qiye de Fazhan yu Zhanwang” (The Development and Prospects of Chinese Private Enterprises), Pp 3-41 in Blue Book of Private Enterprises in China No. 3, edited by Zhang Houyi, Ming Lizhi and Liang Chuanyun. Beijing: Social Sciences Documentation Publishing House. [In Chinese].

Wank, David. 1996. "The Institutional Process of Market Clientelism: Guanxi and Private Business in a South China City". The China Quarterly 820-38.

Wharton, Amy S. 1989. "Gender Segregation in Private-Sector, Public-Sector, and Selfemployed Occupations, 1950-1981.”Social Science Quarterly 70:923-40. 
Whyte, Martin K. William Parish. 1984. Urban Life in Contemporary China. University of Chicago Press.

Wu, Xiaogang. 2002 "Work Units and Income Inequality: The Effects of Market Transition in Urban China" Social Forces 80 (March): 1069-99.

Wu, Xiaogang and Donald Treiman 2002. "The Household Registration System and Social Stratification in China: 1949-1996." Population Studies Center Working Paper, University of Michigan, Ann Arbor

Wu, Xiaogang and Yu Xie. 2002. "Does Market Pay Off? Returns to Education in Urban China." The William Davidson Institute Working Paper Series 454, University of Michigan Business School.

Xie, Yu and Emily Hannum. 1996. "Regional Variation in Earnings Inequality in Reform-Era Urban China." American Journal of Sociology 102: 950-92.

Zhao, Renwei. 1993. "Three Features of the Distribution of Income during the Transition to Reform." Pp. 74-94 in The Distribution of Income in China, edited by Keith Griffin and Renwei Zhao. New York: St. Martin's Press.

Zhou, Dongtao and Zhongzhen Tan (edits) 1996. Zhuangui Zhong de Zhongguo (China in Transition). Beijing: Gaige Press. [in Chinese]

Zhou, Xueguang, Nancy Brandon Tuma, and Phyllis Moen. 1996. "Stratification Dynamics Under State Socialism: The Case of Urban China, 1949-1993”. Social Forces 74(3)-75996

1997 "Institutional Change and Job-Shift Patterns in Urban China, 1949 to 1994" American Sociological Review 62:339-65.

Zhou, Xueguang. 2000a. "Economic Transformation and Income Inequality in Urban China." American Journal of Sociology 105:1135-74.

2000 b "Reply: Beyond the Debate and Toward Substantive Institutional Analysis." American Journal of Sociology 105:1190-95. 


\section{WILLIAM DAVIDSON INSTITUTE WORKING PAPER SERIES}

The Working Paper Series may be downloaded free of charge at: www.wdi.bus.umich.edu

CURRENT AS OF 11/06/02

\begin{tabular}{|c|c|c|}
\hline Publication & Authors & Date \\
\hline $\begin{array}{l}\text { No. 512: Embracing the Market: Entry into Self-Employment in } \\
\text { Transitional China, } 1978-1996\end{array}$ & Xiaogang Wu & Sep. 2002 \\
\hline $\begin{array}{l}\text { No. 511: Opening the Capital Account of Transition Economies: How } \\
\text { Much and How Fast }\end{array}$ & $\begin{array}{l}\text { Daniel Daianu and Radu } \\
\text { Vranceanu }\end{array}$ & Sep. 2002 \\
\hline $\begin{array}{l}\text { No. 510: Bridging "the Great Divide": Countering Financial Repression } \\
\text { in Transition }\end{array}$ & Patrick Conway & May 2002 \\
\hline $\begin{array}{l}\text { No. 509: Change the Regime - Change the Money: Bulgarian } \\
\text { Banknotes, 1885-2001 }\end{array}$ & Adrian E. Tschoegl & May 2002 \\
\hline $\begin{array}{l}\text { No. 508: Differential Rewards to, and Contributions of, Education in } \\
\text { Urban China's Segmented Labor Markets }\end{array}$ & $\begin{array}{l}\text { Margaret Maurer-Fazio and Ngan } \\
\text { Dinh }\end{array}$ & June 2002 \\
\hline $\begin{array}{l}\text { No. 507: Balassa-Samuelson Effect in Transition Economies: The Case } \\
\text { of Slovenia }\end{array}$ & Boštjan Jazbec & Oct. 2002 \\
\hline $\begin{array}{l}\text { No. 506: Explaining Gender Differences in Unemployment with Micro } \\
\text { Data on Flows in Post-Communist Economies }\end{array}$ & $\begin{array}{l}\text { Jana Stefanová Lauerová and } \\
\text { Katherine Terrell }\end{array}$ & Sep. 2002 \\
\hline No. 505: Bank Performance in Transition Economies & $\begin{array}{l}\text { Steven Fries, Damien Neven and } \\
\text { Paul Seabright }\end{array}$ & Sep. 2002 \\
\hline $\begin{array}{l}\text { No. 504: Does the Balassa-Samuelson Hypothesis Hold for Asian } \\
\text { Countries? An Empirical Analysis using Panel Data Cointegration Tests }\end{array}$ & Imed Drine and Christophe Rault & Sep. 2002 \\
\hline No. 503: Job Growth in Early Transition: Comparing Two Paths & $\begin{array}{l}\text { Štěpán Jurajda and Katherine } \\
\text { Terrell }\end{array}$ & Aug. 2002 \\
\hline $\begin{array}{l}\text { No. 502: Job Creation, Destruction and Transition in Poland, 1988- } \\
\text { 1998: Panel Evidence }\end{array}$ & $\begin{array}{l}\text { John E. Jackson and Bogdan } \\
\text { Mach }\end{array}$ & June 2002 \\
\hline $\begin{array}{l}\text { No. 501: Competition, Innovation and Growth in Transition: Exploring } \\
\text { the Interactions between Policies }\end{array}$ & $\begin{array}{l}\text { Philippe Aghion, Wendy Carlin } \\
\text { and Mark Schaffer }\end{array}$ & Mar. 2002 \\
\hline No. 500: Women in the LAC Labor Market: The Remarkable 1990's & $\begin{array}{l}\text { Suzanne Duryea, Alejandra Cox } \\
\text { Edwards and Manuelita Ureta }\end{array}$ & June 2001 \\
\hline $\begin{array}{l}\text { No. 499: Human Capital, Growth and Inequality in Transition } \\
\text { Economies }\end{array}$ & Michael Spagat & July 2002 \\
\hline No. 498: Understanding Czech Long-Term Unemployment & h & Aug. 2002 \\
\hline $\begin{array}{l}\text { No. 497: Rent Seeking and Governme } \\
\text { Application to China's Township-Vill }\end{array}$ & Jiahua Che & Sep. 2002 \\
\hline No. 496: Labor Market Flexibility in Central and East Europe & Jan Svejnar & Aug. 2002 \\
\hline $\begin{array}{l}\text { No. 495: When Information Dominates Comparison: A Panel Data } \\
\text { Analysis Using Russian Subjective Data }\end{array}$ & Claudia Senik & May 2002 \\
\hline No. 494: Corruption and Cross-Border Investment: Firm Level Evidence & $\begin{array}{l}\text { Beata K. Smarzynska and Shang- } \\
\text { Jin Wei }\end{array}$ & Aug. 2002 \\
\hline $\begin{array}{l}\text { No. 493: Modeling Sequences of Long Memory Positive Weakly } \\
\text { Stationary Random Variables }\end{array}$ & Dmitri Koulikov & Aug. 2002 \\
\hline $\begin{array}{l}\text { No. 492: Effects of Ownership and Financial Status on Corporate } \\
\text { Environmental Performance }\end{array}$ & $\begin{array}{l}\text { Dietrich Earnhart and Lubomír } \\
\text { Lízal }\end{array}$ & Aug. 2002 \\
\hline $\begin{array}{l}\text { No. 491: Does Economic Uncertainty Have an Impact on Decisions to } \\
\text { Bear Children? Evidence from Eastern Germany }\end{array}$ & $\begin{array}{l}\text { Sumon Kumar Bhaumik and } \\
\text { Jeffrey B. Nugent }\end{array}$ & July 2002 \\
\hline $\begin{array}{l}\text { No. 490: The Reallocation of Workers and Jobs in Russian Industry: } \\
\text { New Evidence on Measures and Determinants }\end{array}$ & J. David Brown and John S. Earle & Aug. 2002 \\
\hline $\begin{array}{l}\text { No. 489: The Incidence and Cost of Job Loss in a Transition Economy: } \\
\text { Displaced Workers in Estonia, 1989-1999 }\end{array}$ & $\begin{array}{l}\text { Hartmut Lehmann, Kaia Phillips } \\
\text { and Jonathan Wadsworth }\end{array}$ & Aug. 2002 \\
\hline No. 488: Integration: An Empirical Assessment of Russia & $\begin{array}{l}\text { Daniel Berkowitz and David N. } \\
\text { DeJong }\end{array}$ & Feb. 2002 \\
\hline $\begin{array}{l}\text { No. 487: Dual Inflation under the Currency Board } \\
\text { Bulgarian EU Accession }\end{array}$ & $\begin{array}{l}\text { Nikolay Nenovsky and Kalina } \\
\text { Dimitrova }\end{array}$ & July 2002 \\
\hline
\end{tabular}

